\title{
Penilaian Komunitas dan Keterkaitan Lingkungan Terhadap Mangrove di Pesisir Desa Minaluli, Kecamatan Mangoli Utara, Kabupaten Kepulauan Sula Provinsi Maluku Utara
}

\author{
Nebuchadnezzar Akbar ${ }^{1}$,Abdurrachman Baksir¹, Mutmainnah ${ }^{2}$, Firdaut Ismail ${ }^{1}$, Irmalita \\ Tahir $^{1}$, Ikbal Marus ${ }^{1}$, Doni Nurdiansah ${ }^{3}$ dan Iswandi Wahab ${ }^{4}$
}

1 Program Studi lmu Kelautan. FPIK, Universitas Khairun; e-mail: nezzarnebuchad@yahoo..co.id

2 Pemanfaatan Sumberdaya Perikanan. FPIK, Universitas Khairun

${ }^{3}$ Loka Konservasi Biota Laut LIPI Bitung

${ }^{4}$ Fakultas Perikanan dan Kelautan, Universitas Pasifik, Morotai

\begin{abstract}
ABSTRAK
Ekosistem mangrove terdistribusi secara luas di wilayah pesisir desa Minaluli, Kecamatan Mangoli Utara. Ekosistem ini dimanfaatkan masyarakat untuk kegiatan penangkapan ikan, kepiting, udang dan gastropoda. Informasi tentang status dan kondisi lingkungan mangrove di wilayah ini belum tersedia. Tujuan penelitian untuk mengetahui kondisi komunitas dan keterkaitan parameter lingkungan terhadap mangrove. Penelitian dilaksanakan pada Juli 2018 di desa Minaluli, Kecamatan Mangoli Utara. Pengambilan data dilakukan pada empat stasiun menggunakan metode transect quadrant dan spot check. Analisis data mangrove meliputi kerapatan jenis, frekuensi jenis, tutupan, nilai penting jenis dan keanekaragaman jenis. Keterkaitan antara variabel lingkungan seperti substart, suhu, salinitas, $\mathrm{pH}$ air dan $\mathrm{pH}$ tanah dengan mangrove di menggunakan Analisis Komponen Utama (Principle Components Analysis). Hasil penelitian ditemukan tujuh jenis dari tiga famili mangrove. Ketebalan ekosistem mangrove di pesisir Desa Minaluli berdasarkan pengamatan adalah 80 meter (Stasiun I), 110 meter (Stasiun II), 60 meter (Stasiun III) dan 50 meter (Stasiun IV). Nilai kerapatan mangrove tertinggi (Stasiun I), frekuensi tertinggi (Stasiun I), tutupan tertinggi (StasiunI), Nilai penting keseluruhan stasiun 300 dan keanekaragaman tertinggi (Stasiun II). Keanekaragaman jenis masuk dalam kategori sedang. Karakteristik lingkungan mangrove memperlihatkan adanya keterkaitan antara variabel.
\end{abstract}

Kata kunci: Analisis Komponen Utama, Desa Minaluli, Mangrove, Lingkungan, Tutupan Lingkungan

\begin{abstract}
Mangrove ecosystem are widely distributed in coastal areas Minaluli village, north Mangoli subdistrict. This ecosystem used community for fishing, crabs, shrimp and gastropods. Information about status and enviromental conditions of mangroves in this region unavailable. The research goal community assesment and enviromental linkages to mangroves. Data collections in four stations used transect quadrant and spot check. Data analysis mangroves include density, frequency, cover, importance value (INP) and diversity index. The linkages between environmental variables and mangroves are used by the principle components analysis (PCA). The results of the study found seven species from three mangrove families. The thickness of the mangrove ecosystem in the coastal village of Minaluli based on observations is 80 meters (Station I), 110 meters (Station II), 60 meters (Station III) and 50 meters (Station IV). The highest mangrove density value (Station I), highest frequency (Station I), highest cover (StasiunI), important value of overall station 300 and highest diversity (Station II). Diversity types fall into the medium category. The characteristics mangove enverioment show corelation between variabel.
\end{abstract}

Keywords: Frequency Principle Components Analysis, Mangrove, Environment, Cover, Minaluli Village

Citation: Pertama, S., Kedua, P., dan Akhir, P. (2019). Penilaian Komunitas dan Keterkaitan Lingkungan Terhadap Mangrove di Pesisir Desa Minaluli, Kecamatan Mangoli Utara, Kabupaten Kepulauan Sula Provinsi Maluku Utara. Jurnal Ilmu Lingkungan, 17(3), 507-514, doi:10.14710/jil.17.3.507-514

\section{Pendahuluan}

Kecamatan Mangoli Utara, Desa yaitu Minaluli, memiliki ketersedian sumberdaya alam pesisir dan laut disepanjang wilayah pesisir (Baksir dkk.,2018b). Ekosistem mangrove merupakan sumberdaya alam yang terdapat di wilayah pesisir. Ketersediaan ekosistem mangrove yang merata dapat memberikan dampak secara langsung kepada masyarakat (Akbar dkk., 2017; Tahir dkk., 2017; Baksir dkk., 2018a ; Akbar dkk., 2018). Keberadaan hutan mangrove sangatlah penting untuk menjaga keberlangsungan hidup sumberdaya ikan dan juga keberadaan biota di sekitar mangrove (Akbar dkk., 2015). Ekosistem mangrove memiliki fungsi ekologis dan ekonomis. Fungsi ekologis hutan mangrove antara lain sebagai pelindung garis 
pantai, arus, abrasi, mencegah intrusi air laut, habitat, tempat mencari makan (feeding ground), tempat asuhan dan pembesaran (nursery ground), tempat pemijahan (spawning ground) bagi aneka biota perairan, serta sebagai pengatur iklim mikro, sedangkan fungsi ekonominya antara lain sebagai penghasil keperluan rumah tangga, penghasil keperluan industri, dan penghasil bibit (Hogarth, 2007; Saru, 2009; Akbar dkk., 2015; Akbar dkk., 2016). Selain itu, mangrove juga dapat digunakan untuk bahan bangunan, kayu bakar, obat-obatan dan perangkap minyak (Hamilton dan Snedaker, 1984; Feller \& Sitnik, 1996; Kathiresan dan Bingham, 2001).

Kehadiran ekosistem mangrove di Desa Minaluli dapat dimanfaatkan untuk kepentingan penelitian, pengabdian dan edukasi bagi masyarakat. Desa ini memiliki panorama yang indah, sehingga potensi akan pengembangan dan pemanfaatan sangatlah besar. Tahir dkk. (2017), Akbar dkk. (2017) dan Akbar dkk. (2018) mengatakan bahwa kehadiran ekosistem mangrove di pesisir akan memberikan gambaran potensi pengembangan daerah ini menjadi tempat wisata alam berbasis ekologi. Hutan mangrove sangat menentukan dan menunjang tingkat perkembangan sosial dan perekonomian masyarakat pantai (Lumbessy dkk., 2015). Pemanfaatan mangrove secara ekonomi tentunya harus diikuti dengan pola pemanfaatan ramah lingkungan.

Penelitian komunitas mangrove di Indonesia telah banyak diteliti seperti oleh Dharmawan dan Akbar (2016) di taman wisata perairan Gili Matra, Lombok Utara, Teluk Wondamu, Papua Barat (Dharmawan dan Widyastuti, 2017), kawasan pesisir Sidangoli, Kabupaten Halmahera Barat (Akbar dkk., 2015), Pulau Mare, Kota Tidore Kepulauan (Akbar dkk., 2016), Teluk Dodinga, Kabupaten Halmahera Barat (Akbar dkk., 2017), Kawasan Teluk Jailolo Kabupaten Halmahera Barat (Tahir dkk., 2017), Pulau Maitara (Akbar dkk., 2017) dan Pulau Tidore dan sekitarnya (Nurdiansah dan Dharmawan, 2018). Informasi kondisi ekosistem mangrove di pesisir Desa Minaluli dengan menggunakan metode hemispherical photography, menunjukkan bahwa tutupan mangrove termasuk kategori padat, kerapatan tinggi dan indeks nilai penting (INP) setiap jenis mangrove memiliki kisaran nilai antara 31,73-95,55 (Baksir dkk., 2018b). Namun, informasi tentang struktur komunitas mangrove di daerah ini belum dilaporkan, sehingga diperlukan kajian ini. Akbar dkk. (2016) dan Akbar dkk. (2018) menyatakan bahwa pengetahuan ekologi kondisi struktur komunitas hutan mangrove diperlukan untuk memberikan gambaran kondisi terkini, dan dijadikan basis data serta informasi pengelolaan mangrove. Penelitian bertjuan melakukan penilaian kondisi dan keterkaitan lingkungan terhadap mangrove.

\section{Metodologi}

\subsection{Waktu dan Lokasi Penelitian}

Penelitian dilaksanakan pada bulan Juli tahun 2018 di Desa Minaluli, Kecamatan Mangoli Utara, Kabupaten Kepulauan Sula, Propinsi Maluku Utara. Stasiun penelitian ditetapkan sebanyak empat stasiun, yang meliputi bagian utara, selatan, barat dan timur Desa Minaluli. Pemilihan lokasi dilakukan berdasarkan representasi kehadiran mangrove di lokasi penelitian.

\subsection{Pengambilan Data}

Pengambilan contoh mangrove, dilakukan dengan metode transect quadrant dan spot check (Bengen, 2004). Adapun teknik transek dilakukan dengan menarik garis tegak lurus dari arah laut ke darat sepanjang 50 meter sebanyak tiga lintasan dengan jarak antar lintasan 20 meter. Pada setiap transek, data vegetasi dicuplik dengan menggunakan tiga kuadrat berukuran $10 \mathrm{~m}$ x $10 \mathrm{~m}$ dan dalam kuadrant tersebut disusun empat kuadrat berukuran $5 \mathrm{~m}$ x $5 \mathrm{~m}$ untuk pengamatan anakan dan 10 kuadrat kecil berukuran $1 \mathrm{~m}$ x $1 \mathrm{~m}$. Identifikasi vegetasi mangrove dilakukan dengan mengambil contoh biologis berupa komponen daun, bunga, dan buah serta diukur lingkaran batang setiap pohon mangrove setinggi dada. Identifikasi tumbuhan mangrove berdasarkan pedoman dari Noor dkk. (2012).

Ketebalan mangrove di ukur langsung (in situ) dengan menggunakan meteran 200 meter. Penarikan meter dimulai pada bagian terdepan yang bersentuhan dengan laut hingga ke arah daratan ekosistem mangrove.

Pengambilan data parameter lingkungan dilakukan secara langsung di lapangan (in situ) meliputi suhu, salinitas, $\mathrm{pH}$ air dan $\mathrm{pH}$ tanah. Pengukuran suhu mengunakan termometer digital, salinitas menggunakan hand refraktometer, ph air menggunakan $\mathrm{pH}$ meter dan $\mathrm{pH}$ tanah menggunakan Moisture Light Digital Soil Analizer Meter. Data tipe substrat dilakukan pengamatan secara visual.

\subsection{Analisis Data}

Analisis data yang digunakan untuk menentukan kondisi hutan mangrove adalah dengan menggunakan analisis kerapatan (Dharmawan dan Pramudji 2014), frekuensi jenis, tutupan, nilai penting jenis (Bengen, 2004) dan indeks keanekaragaman jenis Shannon- Wienner (Krebs 1989).

Keterkaitan antara variabel lingkungan dengan mangrove menggunakan Analisis Komponen Utama (Principle Components Analysis). Pengujian PCA dilakukan terhadap variabel suhu, salinitas, $\mathrm{pH}$ air, pH tanah dan jenis mangrove. Pengelohan data dilakukan dengan menggunakan program XL STAT.

\section{Hasil dan Pembahasan}

Pengamatan lapangan berdasarkan identifikasi morfologi seperti ciri dari bentuk akar, buah dan daun, maka diperoleh sebanyak tujuh jenis dari tiga famili (Tabel 1). 


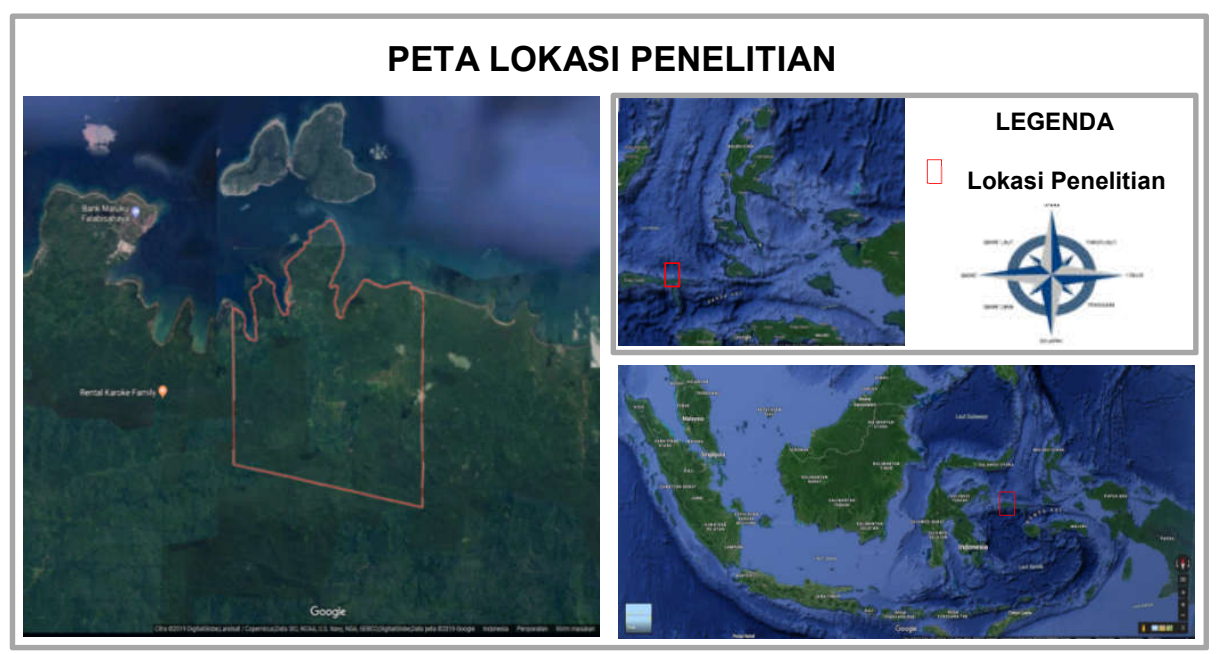

Gambar 1. Peta lokasi penelitian

Tabel 1. Komposisi Jenis Mangrove di Desa Minaluli.

\begin{tabular}{clll}
\hline No & Famili & \multicolumn{1}{c}{ Spesies } & \multicolumn{1}{c}{ Nama Indonesia } \\
\hline 1 & Rhizophoraceae & Rhizophora stylosa & Bakau Merah \\
& & Rhizophora apiculata & Bakau \\
& & Rhizophora mucronata & Bakau hitam \\
& & Ceriops stagal & Tengar/ M. Kuning \\
& & Bruguiera gymnorrhiza & Tanjang \\
3 & Meliaceae & Xylocarpus granatum & M. Apel/Nyirih \\
\hline
\end{tabular}

Hasil identifikasi dan pengamatan menunjukkan bahwa jenis mangrove dari Famili Rhizophoraceae paling dominan sebanyak lima jenis dan famili Sonneratiaceae dan Meliaceae hanya ditemukan satu jenis (Tabel 1). Karakteristik oseanografi dan keadaan substrat yang sesuai akan memberikan peluang kehadiran jenis mangrove yang tinggi di daerah pantai. Pada tiap stasiun menunjukkan adanya keseragaman tipe topografi pada daerah pantai di lokasi penelitian.

Komposisi jenis mangrove Rhizophoraceae memiliki dominansi yang tinggi. Menurut Akbar dkk. $(2015 ; 2016 ; 2017 ; 2018)$ bahwa habitat turut mendukung aspek ekologi, biologi dan fisologi dari famili ini. Penelitian Akbar dkk. (2015;2016;2017;2018) juga menemukan bahwa famili Rhizophoraceae ditemukan di Pulau Mare Kota Tidore Kepulauan, Pesisir Sidangoli Kabupaten Halmahera Barat, Pulau Maitara Tidore Kepulauan, Teluk Dodinga Kabupaten Halmahera Barat dan pesisir Desa Tewe, Kabupaten Halmahera Barat dalam kondisi paling dominan. Agustina dkk. (2016) menyebutkan bahwa jenis ini juga ditemukan pada Pulau Enggano. Nurdiansah dan Dharmawan (2018) juga memperoleh spesies ini di Wilayah Pesisir Pulau Tidore dan Sekitarnya. Penelitian Parmadi dkk. (2016) juga menemukan jenis ini paling dominan dikawasan Kuala Idi, Kabupaten Aceh Timur. Selain itu Juwita dkk. (2015) dalam penelitian menemukan famili Rhizophoraceae merupakan jenis mangrove yang mendominasi wilayah Kecamatan Simpang Pesak, Belitung Timur. Berbagai hasil peneltian yang ditemukan, menunjukan bahwa Rhizopoceae merupakan jenis yang tersebar luas dan mendominasi di sebagian besar wilayah Indonesia.

Secara umum dominasi substrat pada lokasi penelitian adalah pasir berlumpur. Hal ini selaras dengan hasil penelitian Kaunang dan Kimbal (2009) yang melaporkan 509 bahwa famili Rhizophoraceae juga mendominasi kawasan hutan mangrove di Taman Nasional Bunaken, Sulawesi Selatan. Pengamatan jenis substrat diperoleh tipe lumpur berpasir, yang sangat sesuai dengan pertumbuhan famili ini. Hasil penelitian Akbar dkk. (2015;2016;2017a;2017b; 2018) di Pulau Mare Kota Tidore Kepulauan, Pesisir Sidangoli Kabupaten Halmahera Barat, Pulau Maitara Tidore Kepulauan, Teluk Dodinga Kabupaten Halmahera Barat dan di pesisir Desa Tewe, Kabupaten Halmahera Barat. Menurut Hardjowigeno (2001), daerah- dengan tanah berlumpur didominasi oleh Rhizophora Sp. . Nybakken (1988) dan Agustini dkk. (2016) menyatakan bahwa zona Rhizopora terletak pada tepi yang menghadap ke arah laut dan kondisi substratnya lumpur berpasir yang selalu tergenang pada saat pasang normal. Kondisi lingkungan lumpur berpasir akan mendukung kehadiran dan merupakan tempat tumbuh berkembang famili Rhizophoraceae (Ernanto dkk., 2010; Noor dkk., 2012). Karakteristik pulau dengan ciri pantai landai dan luas ke arah laut memberikan tempat untuk hidup dan berkembangnya mangrove. Kusmana dkk. (2003) menyatakan bahwa topografi dapat mempengaruhi komposisi jenis, distribusi jenis dan lebar hutan mangrove.

Komposisi dan distribusi mangrove merupakan ciri umum jenis mangrove yang ditemukan di Maluku Utara (Tabel1). Nurdiansah dan Dharmawan (2018) memperoleh komposisi jenis mangrove yang mirip dengan yang ditemukan pada wilayah pesisir Pulau Tidore dan sekitarnya. Kondisi lingkungan mempengaruhi frekuensi kehadiran jenis pada setiap lokasi dan juga mempengaruhi komposisi jenis yang ditemukan. Akbar dkk. (2017) mengatakan kondisi topografi yang landai dan substrat yang sesuai serta dipengaruhi oleh kondisi oseanografi merupakan penyebab tingginya kehadiran jenis mangrove. Akbar dkk. (2016) menjelaskan bahwa kondisi lingkungan 
juga turut memberikan andil terhadap kehadirannya seperti halnya subsrat, pasang surut, gelombang, morfologi pantai dan pola arus. Selain itu, karakteristik pulau dengan ciri pantai yang bervariasi memberikan ruang untuk hidup dan berkembangnya mangrove. Kusmana (2003) menyatakan bahwa topografi dapat mempengaruhi komposisi jenis, distribusi jenis dan lebar hutan mangrove. Selanjutnya Fajar dkk. (2013) mengatakan bahwa kemiringan alas atau topografi mempengaruhi distribusi dan lebar hutan mangrove.

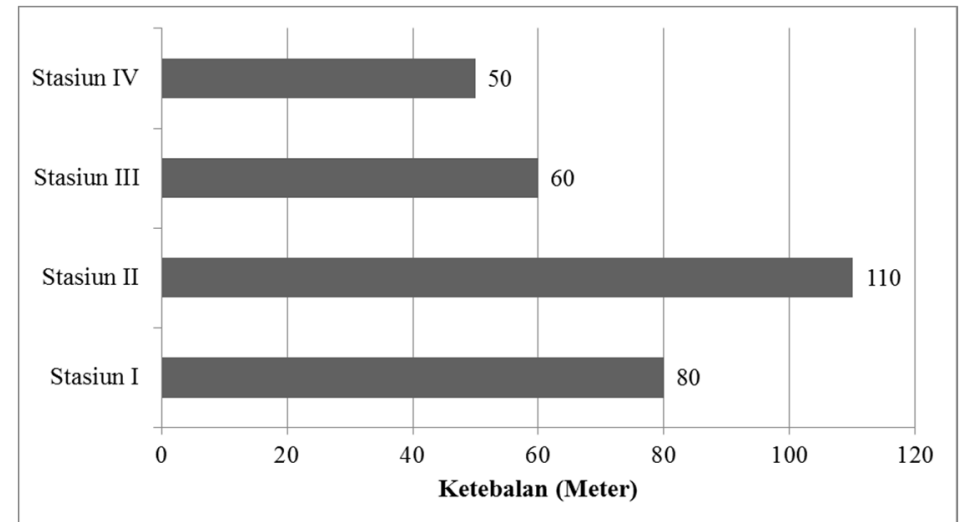

Gambar 2. Ketebalan Ekosistem Mangrove di Desa Minalui

Ketebalan ekosistem mangrove di pesisir Desa Minaluli berdasarkan pengamatan adalah 80 meter (Stasiun I), 110 meter (Stasiun II), 60 meter (Stasiun III) dan 50 meter (Stasiun IV) (Gambar 2). Lokasi stasiun I berada tepat pada bagian dalam teluk dengan kondisi perairan yang tenang, kondisi substrat lumpur pada bagian laut dan pasir darat, sehingga distribusi mangrove pada umumnya di wilayah terkena genangan air adalah Rhizophora sp dan pada bagian menuju daratan ditemukan jenis lainnya. Stasiun II terletak sebelah kanan teluk yang mirip dengan stasiun I, dengan demikian memungkinkan tidak adanya pengaruh gelombang dan arus secara signifikan, hal ini dikarenakan stasiun II terletak masuk kedalam teluk. Kondisi substrat berlumpur merupakan daerah yang cocok untuk ditumbuhi jenis Rhizophora sp, sehingga spesies ini lebih mendominasi.

Ketebalan mangrove stasiun II lebih tinggi dibandingkan lokasi lain, dikarenakan pada bagian ini substrat berlumpur terdistribusi jauh hingga kearah dalam daratan. Kondisi ini memberikan peluang kehadiran mangrove ke arah darat lebih tinggi sehingga mempengaruhi ketebalan mangrove. Stasiun III terletak pada kanan teluk pada bagian tengah sebelah kanan teluk dengan kondisi mangrove baik, namun memiliki ketebalan rendah. Hal ini dikarenakan substrat lumpur mendominasi pada daerah pantai, sehingga tidak banyak ditemukan spesies mangrove. Sedangkan stasiun IV terletak pada bagian luar teluk yang mendapatkan pengaruh gelombang dan arus secara signifikan. Hal ini mengakibatkan ketebalan dan komposisi jenis mangrove lebih rendah dibandingkan lokasi lain. Kondisi topografi pantai pada daerah ini curam, yang menyebabkan penyebaran mangrove dan substrat menjadi terbatas kearah laut.

Secara umum variasi ketebalan mangrove yang ditemukan pada stasiun I, III dan IV tidak begitu berbeda, namun berbeda dengan stasiun IV (Gambar 2). Hal ini disebabkan karena topografi pantai, kondisi substrat, daratan yang menjorok jauh ke arah pantai dan kontur pantai yang landai. Akbar (2015) mengatakan pada daerah yang landai memiliki ruang yang luas untuk ditumbuhi oleh mangrove sehingga distribusi jenis mangrove meluas. Akbar dkk. (2015) menemukan perbedaan ketebalan mangrove disebabkan karena letak stasiun dan kondisi pantai di daerah pengamatan yang berbeda. Akbar dkk. (2016) menyebutkan bahwa perbedaan variasi ini diakibatkan karena setiap stasiun memiliki tipe pantai yang berbeda. Hasil penelitian tentang kondisi ketebalan yang bervariasi juga dilaporkan Setiawan (2013) yang menemukan tingkat ketebalan tinggi (200-300 meter) yang berlokasi di Desa TongkeTongke dan mangrove dengan tingkat ketebalan sedang (100-150 meter) yang berlokasi di Desa Panaikang. Akbar dkk. (2015) memperoleh ketebalan berkisar 145-750 meter pada mangrove di kawasan pesisir Sidangoli Kabupaten Halmahera Barat, Maluku Utara, Akbar dkk. (2016) memperoleh ketebalan mangrove berkisar 85-150 meter di Pulau Mare, Kota Tidore Kepulauan, Akbar dkk. (2017) juga melaporkan ketebalan mangrove di Teluk Dodinga, Kab. Halmahera Barat berkisar diantara 60-130 meter dan Akbar dkk. (2018) menemukan ketebalan mangrove berkisar diantara 321-410 meter di Desa Tewe, Kabupaten Halmahera Barat. Berbagai penelitian diatas juga menemukan kondisi topografi dan jenis mangrove yang mirip dengan yang ditemukan pada desa Minaluli. Penjelasan berbgai penelitian diatas memberikan gambaran bahwa ratarata variasi ketebalan mangrove terjadi diakibatkan kondisi sebaran substrat pada suatu wilayah.

Kondisi kerapatan komunitas mangrove di pesisir desa Minaluli masuk dalam kategori baik dengan kriteria sangat padat berdasarkan keputusan Menteri Negara Lingkungan Hidup (Tabel 3). 
Tabel 2. Struktur komunitas mangrove setiap stasiun.

\begin{tabular}{ccccc}
\hline Jumlah Total & Stasiun 1 & Stasiun 2 & Stasiun 3 & Stasiun 4 \\
\hline $\mathrm{Di}$ & 3.033 pohon/ha & 2.783 pohon/ha & 2.017 pohon/ha & 1.600 pohon/ha \\
$\mathrm{Rdi}$ & $100 \%$ & $100 \%$ & $100 \%$ & $100 \%$ \\
$\mathrm{Fi}$ & $350 \mathrm{ind} / \mathrm{ha}$ & $267 \mathrm{ind} / \mathrm{ha}$ & $267 \mathrm{ind} / \mathrm{ha}$ & $233 \mathrm{ind} / \mathrm{ha}$ \\
$\mathrm{Fri}$ & $100 \%$ & $100 \%$ & $100 \%$ & $100 \%$ \\
$\mathrm{Ci}$ & 8,46 & 7,04 & 8,19 & 6,7 \\
$\mathrm{Rci}$ & $100 \%$ & $100 \%$ & $100 \%$ & $100 \%$ \\
$\mathrm{H}$ & 1,82 & 1,30 & 1,16 & 1,07 \\
$\mathrm{NP}$ & $300 \%$ & $300 \%$ & $300 \%$ & $300 \%$ \\
\hline
\end{tabular}

Tabel 3. Kriteria baku kerusakan mangrove (Kepmen Lingkungan Hidup, 2004).

\begin{tabular}{clcc}
\hline & Kriteria & Penutupan & Kerapatan (pohon/ha) \\
\hline \multirow{2}{*}{ Baik } & Sangat Padat & $\geq 75$ & $\geq 1500$ \\
& Sedang & $\geq 50-<75$ & $\geq 1000-<1500$ \\
Rusak & Jarang & $<50$ & $<1000$ \\
\hline
\end{tabular}

Keterangan: * = kriteria baku kerusakan mangrove berdasarkan Keputusan Menteri Negara Lingkungan Hidup Nomor 201

Tahun 2004

Nilai kehadiran jenis ditemukan paling tinggi pada stasiun I yakni 3,50 ind $/ \mathrm{m}^{2}$, diikuti stasiun II dan III dengan nilai $2,67 \mathrm{ind} / \mathrm{m}^{2}$ dan terendah pada stasiun IV yakni 2,33 ind $/ \mathrm{m}^{2}$. Frekuensi jenis menggambarkan kesempatan ataupun kemungkinan dan peluang dapat tumbuh dan ditemukannya suatu jenis dalam suatu areal lokasi yang menjadi areal pengamatan. Persentasi tutupan tertinggi pada komunitas mangrove ditemukan pada stasiun stasiun I yaitu 8,46, kemudian stasiun III sebesar 8,19, diikuti stasiun II dengan nilai 7,04 dan terendah pada stasiun IV yakni 6,7. Nilai penting vegetasi mangrove secara keseluruhan memiliki kesamaan yaitu $300 \%$ (Tabel 9).

Secara umum kondisi lingkungan di kawasan pesisir desa Minaluli dalam kondisi baik. Hasil pengukuran parameter lingkungan menunjukan adanya kecocokan habitat dan lingkungan untuk pertemubuhan mangrove. Akitivitas masyarakat pesisir untuk pemanfaatan mangrove secara di daerah ini sangat rendah. Pengetahuan lokal akan peran dan fungsi mangrove secara turun temurun, di implementasikan dalam kehidupan. Larangan penebangan dan pengambilan pohon mangrove yang masih hidup, juga diterakkan aparat desa. Hal ini untuk meminimalisir terjadinya degradasi hutan mangrove. Nilai kearifan lokal yang kuat, memberikan pengaruh terhadap kelestarian mangrove di desa Minaluli. Keseluruhan hasil analisis keanekaragaman tingkat stasiun menunjukan adanya variasi nilai setiap stasiun pengamatan (Gambar 3). Berdasarkan kriteria keanekaragaman jenis, maka empat stasiun pengamatan masuk dalam kriteria keanekaragaman sedang.

Kondisi sosial ekonomi masyarakat turut memberikan kontribusi terhadap distribusi dan tingkat keberlangsungan hidup ekosistem mangrove. Pengetahuan akan pentingnya nilai ekologi dan kearifan lokal disuatu daerah, memberikan pengaruh terhadap ketersediaan ekosistem mangrove di wilayah pesisir.

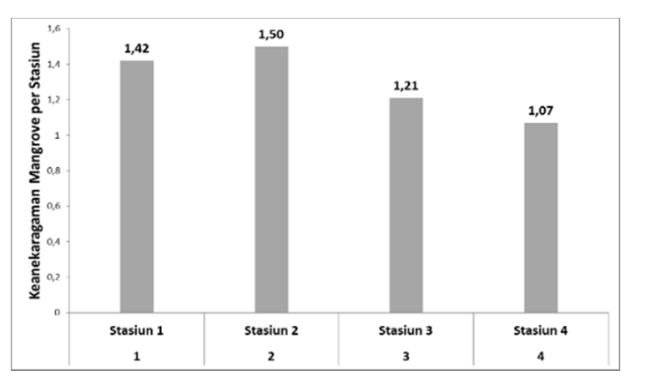

Gambar 3. Keanekaragaman mangrove per stasiun

Tingginya nilai kerapatan pada stasiun I dan II diakibatkan persamaan kondisi habitat dan ekologi. Pada kedua stasiun ini kondisi topografi pantai yang dangkal dan memiliki ruang yang luas untuk ditumbuhi mangrove. Secara ekologi keberadaan substrat yang bervariasi dan parameter lingkungan lainnya mendukung pertumbuhan mangrove. Sedangkan pada stasiun III dan IV kondisi lingkungan mendapatkan pengaruh gelombang yang cukup tinggi, topografi pantai yang curam dan ruang yang sempit memberikan keterbatasan pada vegetasi mangrove untuk tumbuh dan berkembang. Namun secara keseluruhan memperlihatkan bahwa kerapatan komunitas mangrove masuk kriteria tinggi/baik. Baksir dkk. (2018b) memperoleh hasil penelitian kerapatan mangrove di lokasi ini masuk dalam kategori sedang hingga sangat padat dengan nilai kisaran diantara 1.067-2.022 pohon/ha. Kerapatan dari suatu jenis merupakan nilai yang menunjukkan jumlah atau banyaknya individu suatu jenis per satuan luas. Bengen (2004) mengatakan makin besar kerapatan suatu jenis, makin banyak individu jenis tersebut per satuan luas. Studi kasus kondisi mangrove di wilayah Indonesia Barat khususnya Kecamatan Ujung Pangkah Kabupaten Gresik Provinsi Jawa Timur, terjadi peningkatan kerapatan mangrove 42.30 hektar menjadi seluas 250.92 hektar pada tahun 
2016 diakibatkan proses akresi terhadap lahan meningkat (Prasetyo dkk., 2017).

Nilai frekuensi jenis memperlihatkan adanya peluang kehadiran yang cukup tinggi. Akbar dkk. (2017) mengatakan bahwa nilai frekuensi jenis yang diperoleh memperlihatkan bahwa peluang akan kehadiran mangrove disetiap lokasi sangat besar, sehingga memberikan peluang kestabilan mangrove di lokasi ini. Tingginya frekuensi jenis mangrove juga diperoleh Akbar dkk. (2015;2016;2017a; 2017b;2018) di pesisir Pulau Sidangoli, Pulau Mare, Teluk Dodinga, Pulau Maitara dan pesisir desa Tewe serta Agustini dkk. (2016) di Desa Kahyapu Pulau Enggano, Sumatera. Walsh (1974) dalam Supriharyono (2002) mengatakan substrat tanah menentukan kehidupan hutan mangrove, tipe substrat yang cocok untuk pertumbuhan hutan mangrove adalah lumpur lunak, yang mengandung silt clay dan bahan-bahan organik yang lembut.

Nilai tutupan mangrove baik, hal ini berhubungan erat dengan lingkar batang pohon (Akbar dkk., 2015). Mangrove yang memiliki ukuran lingkar batang yang besar dengan tutupan kenopi lebat, turut mempengaruhi penutupan pada setiap lokasi. Akbar dkk. (2017) mengatakan tutupan jenis tertinggi disebabkan karena ukuran lingkar batang yang besar dengan tutupan kanopi yang tinggi. Indeks Nilai Penting (INP) merupakan salah suatu indeks yang dihitung berdasarkan jumlah yang didapatkan untuk menentukan tingkat dominasi jenis dalam suatu komunitas tumbuhan (Parmadi dkk., 2016). Nilai penting jenis yang ditemukan paling dominan pada famili Rhizophoraceae, dikarenakan jenis ini paling dominan pada setiap lokasi. Selain itu tingkat kerapatan dan frekuensi jenis dan tutupan memberikan pengaruh terhadap nilai penting.

Penelitian tentang struktur komunitas mangrove telah dilakukan Akbar dkk. (2015) di kawasan pesisir Sidangoli Kabupaten Halmahera Barat, Maluku Utara, dengan kisaran nilai kerapatan 0,20 -0,33 ind $/ \mathrm{m}^{2}$, tutupan berkisar 24,39-30, frekuensi jenis dengan nilai kisaran 4-6 ind $/ \mathrm{m}^{2}$ dan nilai penting 300 . Juwita dkk. (2015) juga melaporkan kondisi mangrove dengan kisaran indeks nilai penting 28,30-69,94 menunjukkan mangrove yang berperan dalam ekosistem tersebut dan dalam status mutu baik yang didukung dengan kerapatan 460 pohon/hektar. Akbar dkk. (2016) juga melaporkan struktur komunitas mangrove di Pulau Mare, Tidore Kepulauan dengan kondisi ekosistem ini masuk dalam kategori kurang sehat dan mempunyai keanekaragaman jenis rendah. Laporan Akbar dkk. (2017a) di Teluk Dodingan juga diperoleh kondisi struktur komunitas mangrove yang bervariasi dan Akbar dkk. (2017b) menemukan keseluruhan kerapatan stasiun yaitu 215.78 batang/hektar, frekuensi 722.22 batang/ hektar, tutupan $189.29 \%$ dan nilai penting 300 tiap stasiun di pesisir pulau Maitara, Kabupaten Tidore Kepulauan. Penelitian Akbar dkk. (2018) menemukan struktur komunitas hutan mangrove di Desa Tewe berdasarkan indeks ekologi (nilai kerapatan, frekuensi jenis, tutupan dan nilai penting) baik, sedangkan keanekaragaman spesies masngrove termasuk dalam kategori sedang. Kemudian Nurdiansah dan Dharmawan (2017) menemukan kerapatan pohon juga termasuk kategori sedang yaitu $1.275 \pm 838$ pohon/ha di wilayah pesisir pulau Tidore dan sekitarnya.

Aktifitas pengrusakan lingkungan seperti potasium, bom dan alat penangkapan tidak ramah lingkungan tidak ditemukan. Dengan demikian akan bepengaruh terhadap keberagaman dan ketersediaan sumberdaya alam di pesisir Minaluli. Masiyah dan Monika (2017) mengatakan kerusakan lingkungan berdampak pada aktivitas manusia dan lingkungan, seperti rusaknya biota laut, terancamnya pemukiman nelayan, terancamnya mata pencaharian nelayan dan sebagainya.

Nilai keanekaragaman mangrove masuk dalam kriteria sedang. Penelitian dengan hasil yang sama juga ditemukan Mukhlisi dkk. (2013) di Desa Sidodadi Kecamatan Padang Cermin Kabupaten Pesawaran, Provinsi Lampung. Kemudian Akbar dkk. (2017a), Teluk Dodonga, Kabupaten Halamhera Barat. Provinsi Maluku Utara. Selain itu Agustini dkk. (2016) juga dimana tingkat keanekaragaman jenis mangrove masuk dalam kategori sedang di Pulau Enggano. Hasil penelitian berbeda ditemukan Akbar dkk. (2016 dan 2017b) di Pulau Mare dan Pulau Maitara, Kota Tidore Kepulauan dimana keanekakaragaman pada daerah ini rendah. Akbar dkk. (2018) memperoleh nilai keanekaragaman spesies masngrove termasuk dalam kategori sedang di kawasan pesisir desa Tewe, Halmahera Barat dengan nilai $H^{\prime}=1,16-1,82$. Indriyanto (2006) menjelaskan bahwa keanekaragaman jenis juga dapat digunakan untuk mengukur stabilitas komunitas, yaitu kemampuan suatu komunitas untuk menjaga dirinya tetap stabil.

Nilai keanekaragaman yang diperoleh memperlihatkan adanya variasi antar stasiun, hal ini disebabkan karena komposisi dan jumlah jenis yang ditemukan setiap lokasi berbeda-beda. Nilai keanekaragaman suatu komunitas sangat bergantung pada jumlah jenis dan jumlah individu yang terdapat pada komunitas tersebut. Secara alami keanekaragaman jenis hutan mangrove memang lebih rendah bila dibandingkan hutan tropis namun memiliki struktur dan fungsi yang mampu mempertahankan hidupnya pada lingkungan ekstrim di zona pasang surut (Duke dkk., 1998). Ekosistem mangrove juga memiliki produktivitas primer yang tinggi namun dapat dengan mudah berubah bila ada gangguan terutama yang bersifat antropogenik (Hogart 1998). Sebagian besar perubahan keanekaragaman jenis dan struktur vegetasi hutan mangrove disebabkan oleh aktivitas antropogenik pada kawasan pesisir (Alongi 2002; Thampanya dkk., 2006). Permasalahan tersebut terjadi pada hampir semua kawasan hutan mangrove terutama pada negara-negara berkembang termasuk di Indonesia. Nilai indeks keanekaragaman jenis mangrove ini lebih redah dari Pulau Sebatik, Kalimantan Timur dengan 
$H^{\prime}=$ 0,64-1,55 (Ardiansyah dkk., 2012), kawasan hutan mangrove di Banyuasin, Sumatera Selatan dengan $\mathrm{H}^{\prime}=0,34-0,88$ (Indriani dkk., 2009), Agustini dkk. (2016) melaporkan nilai keanekaragaman yang ditemukan di pulau Enggano berkisar antara 1,532,34 Akbar dkk. (2017b) di Teluk Dodinga, Kabupaten Halmahera Barat. Provinsi Maluku Utara dan lebih tinggi dari laporan Akbar dkk. (2017b) di Pulau Maitara, Kota Tidore Kepulauan dengan $\mathrm{H}^{\prime}=$ yaitu 0.495. Perbedaan hasil penelitian yang ditemukan diakibatkan perbedaan komposisi, jumlah,ekologi, morfologi pantai dan tingkat pemanfaatan pada setiap daerah pengamatan. Tiap lokasi mangrove mempunyai keanekaragaman vegetasi yang berbeda, bergantung pada umur mangrove tersebut (Kjerfve dan Lacerda 1993; Dodd dkk., 1998; Gunarto 2004).

\section{Keterkaitan Mangrove dengan lingkungan}

Hasil analisis PCA sebaran parameter di setiap stasiun yaitu analisis korespondensi utama (PCA) terpusat pada sumbu utama yaitu F1 (55.91\%) dan F2 (36.11\%) dengan ragam total sebesar (92.02\%) (Gambar 4). Sumbu F1 positif dicirikan oleh variabel suhu, DO, dan pH air yang tinggi pada stasiun 2 dan stasiun 4, sedangkan sumbu F2 negatif dicirikan oleh variabel salinitas yang tinggi pada stasiun 2 dan stasiun 4 (Gambar 5).

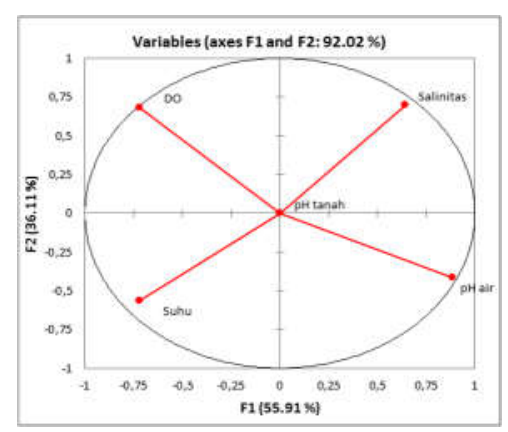

Gambar 4. Analisis korespondensi utama (PCA) sebaran parameter lingkungan

Poedjirahajoe dkk. (2017) melakukan penelitian penggunaan principal component analysis dalam distribusi spasial vegetasi Mangrove di Pantai Utara Pemalang. Hasil analisis menunjukan bahwa dari lima variabel karakteristik habitat menunjukkan bahwa seluruh variabel memiliki pengaruh nyata terhadap variabel baru.

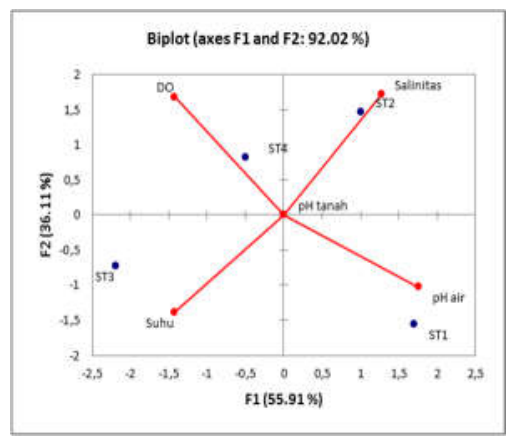

Gambar 5. Sebaran spasial jenis mangrove berdasarkan karakteristik habitat

Analisis korespondensi utama (CA) menunjukkan bahwa sebaran mangrove terpusat pada tiga sumbu dengan nilai sumbu F1 65.28\%, F2. $22.92 \%$, dan sumbu F3 11.79\% dengan ragam total mencapai 100\% (Gambar 6). Dengan korelasi membentuk tiga kelompok. Kelompok pertama mengasosiasikan Xylocarpus granatum, dan jenis Rhizophora mucronata pada stasiun 2.

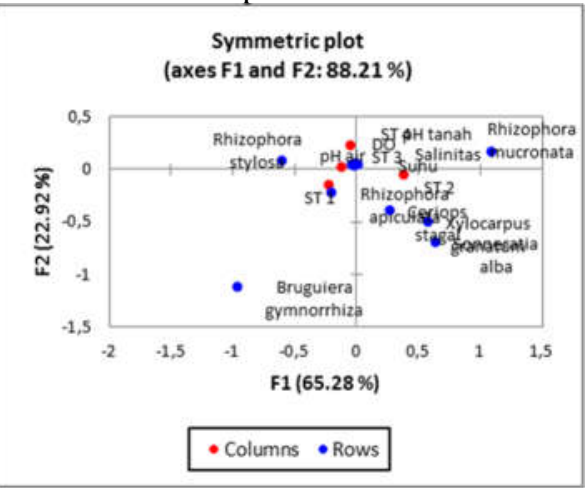

Gambar 6. Analisis CA parameter lingkungan dengan kepadatan mangrove

Kelompok 2 mengasosiasikan jenis Rhizophora stylosa pada stasiun 1. Kelompok ketiga mengasosiasikan jenis Rhizophora apiculata, Ceriops stagal, Bruguiera gymnorrhiza, dan Sonneratia alba pada stasiun 4.

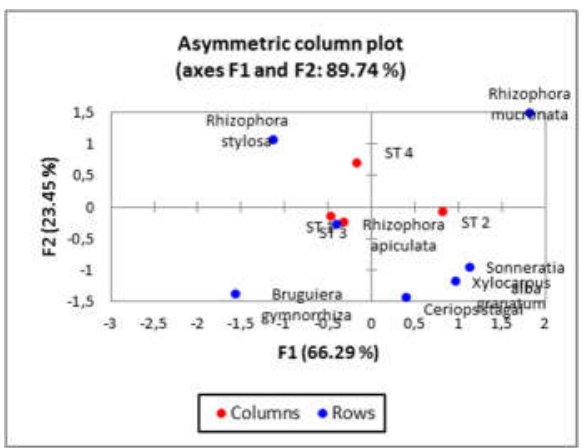

Gambar 7. Hasil analisis CA untuk sebaran kepadatan mangrove.

Hasil ini menunjukkan bahwa distribusi jenis mangrove pada keseluruhan stasiun penelitian terpusat pada sumbu utama F1 sebesar $66.29 \%$ dan F2 $23.45 \%$ dengan ragam total sebesar $89.74 \%$, dengan korelasi membentuk 2 kelompok. Kelompok pertama jenis mangrove Xylocarpus granatum, Sonneratia alba, dan Rhizophora mucronata pada stasiun 2 (Gambar 7). Kelompok kedua jenis Rhizophora stylosa, Rhizophora apiculata, dan Bruguiera gymnorrhiza pada stasiun 4 (Gambar 7).

\section{Kesimpulan}

Indeks ekologi ekosistem mangrove diperoleh ketebalan ekosistem mangrove dipesisir Desa Minaluli berdasarkan pengamatan adalah 80 meter (Stasiun I), 110 meter (Stasiun II), 60 meter (Stasiun III) dan 50 meter (Stasiun IV). Analisis struktur komunitas mangrove kerapatan jenis mangrove masuk dalam kriteria baik/sangat padat. Nilai kehadiran yang tinggi pada setiap stasiun. Persentasi tutupan secara ekologi memperlihatkan kondisi cukup baik. Nilai penting vegetasi mangrove yang ditemukan secara keseluruhan memperlihatkan (C) 2019, Program Studi Ilmu Lingkungan Sekolah Pascasarjana UNDIP 
bahwa secara ekologi masih memberikan peranan penting. Berdasarkan kriteria keanekaragaman jenis, maka empat stasiun pengamatan masuk dalam kriteria keanekaragaman sedang. Keseluruhan analisis variabel karakteristik lingkungan memperlihatkan seluruh variabel memiliki pengaruh besar terhdap mangrove.

\section{DAFTAR PUSTAKA}

Akbar, N., A. Baksir, dan I. Tahir. 2015. Struktur Komunitas Ekosistem Mangrove di Kawasan Pesisir Sidangoli Kabupaten Halmahera Barat, Maluku Utara. Depik Jurnal 4 (3) : 132-143.

Akbar, N., A. Baksir, I. Tahir, dan D.Arafat . 2016. Struktur Komunitas Mangrove di Pulau Mare, Kota Tidore Kepulauan, Provinsi Maluku Utara. Depik Jurnal, 5(3): 133-142.

Akbar, N., I. Marus, I. Haji, S.Abdullah, S.Umalekhoa, F.S.I. Ibrahim, M. Ahmad, A. Ibrahim, A. Kahar, dan I. Tahir. 2017a. Struktur Komunitas Hutan Mangrove Di Teluk Dodinga, Kabupaten Halmahera Barat Provinsi Maluku Utara. Jurnal Enggano, 2 (1); 78-89

Akbar, N., N.Haya, A. Baksir, Z.A. Harahap, I.Tahir, Y. Ramili dan R. Kotta. 2017b. Struktur Komunitas Dan Pemetaan Ekosistem Mangrove Di Pesisir Pulau Maitara, Provinsi Maluku Utara, Indonesia. Depik jurnal, 6 (2): 167-181

Akbar, N., A. Ibrahim, I. Haji, I. Tahir, F. Ismail, M. Ahmad dan R. Kotta. 2018. Struktur Komunitas Mangrove di Desa Tewe, Kecamatan Jailolo Selatan, Kabupaten Halmahera Barat Provinsi Maluku Utara. Jurnal Enggano, 3 (1): 81-97

Agustini, N.T., Z. Ta'alidin dan D. Purnama. 2016. Struktur Komunitas Mangrove Di Desa Kahyapu Pulau Enggano. Jurnal Enggano, 1(1): 19-31

Aksornkoae, S. 1993. Ecology and Management of Mangroves. Bangkok: IUCN

Alikodra, H.S.1998. Kebijakan Hutan Mangrove Dilihat dari Lingkungan Hidup. Prosiding Seminar VI Ekosistem Hutan Mangrove : 33-34.

Alongi, D.M. 2002. Present State And Future Of The World's Mangrove Forests. Environmental Conservation 29 (3) : 331-349

Ardiansyah, W.I., R. Pribadi dan S. Nirwan. 2012. Struktur Dan Komposisi Vegetasi Mangrove Di Kawasan Pesisir Pulau Sebatik, Kabupaten Nunukan, Kalimantan Timur. Journal of Marine Research 1 (2) : 203-215

Baksir, A., N. Akbar, I.Tahir, I. Haji, M. Ahmad dan R. Kotta. 2018. Struktur Komunitas Hutan Mangrove Di Pulau Sibu Kota Tidore Kepulauan Provinsi Maluku Utara. Jurnal Enggano (3) 2 : 178-196

Baksir, A., Mutmainnah, N. Akbar dan F. Ismail. 2018. Penilaian Kondisi Menggunakan Metode Hemispherical Photography Pada Ekosistem Mangrove Di Pesisir Desa Minaluli, Kecamatan Mangoli Utara, Kabupaten Kepulauan Sula,
Provinsi Maluku Utara. Jurnal Sumberdaya Akuatik Indopasifik 2 (2) : 69-80

Bengen, D.G. 2000. Teknik Pengambilan Contoh Dan Analisis Data Biofisik Sumberdaya Pesisir. PKSPL-FPIK. IPB. Bogor. 88 hlm.

Bengen, D.G. 2002. Ekosistem Dan Sumberdaya Alam Pesisir Dan Laut Serta Prinsip Pengelolaannya. Pusat Kajian Sumberdaya Pesisir dan Lautan, Institut Pertanian Bogor, Bogor.

Bengen, D. G. 2004. Pedoman Teknis Pengenalan dan Pengelolaan Ekosistem mangrove. Pusat Kajian Sumberdaya Pesisir Dan Lautan. IPB. Bogor.

Dharmawan, I.W.E dan N.Akbar. 2016. Status Terkini Kondisi Komunitas Mangrove Di Taman Wisata Perairan Gili Matra, Lombok Utara, NTB. Prosiding Seminar Nasional Kemaritiman dan Sumberdaya Pulau-Pulau Kecil, 1 (1) : 38-43

Dharmawan, I.W.E dan A.Widyastuti. 2017. Pristine Mangrove Community In Wondama Gulf, West Papua, Indonesia. Marine Research Indonesia, 42 (2) : 67-76

Dodd, R.S., Z. Afzal-Rafii, F. Fromard and F. Blasco. 1998. Evolutionary Diversity Among Atlantic Coast Mangroves. Acta Oecologica 19: 323-330.

Duke, N.C., M C. Ball and J.C. Ellison. 1998. Factors Influencing Biodiversity And Distributional Gradients In Mangroves. Global Ecology and Biogeography Letters 7 (1) : 27-47.

Ernanto, R., F. Agustriani dan R. Aryawati. 2010. Struktur Komunitas Gastropoda Pada Ekosistem Mangrove Di Muara Sungai Batang Ogan Komering Ilir Sumatera Selatan. Maspari Journal 1:73-78.

Fajar, A., D. Oetama dan A. Afu. 2013. Studi Kesesuaian Jenis untuk Perencanaan Rehabilitasi Ekosistem Mangrovedi Desa Wawatu Kecamatan Moramo Utara Kabupaten Konawe Selatan. Jurnal Mina Laut Indonesia, 2 (12) ; 164-176

Feller, I.C. and M. Sitnik. 1996. Mangrove Ecology Workshop Manual. Smithsonian Institut, Washington DC.

Gunarto. 2004. Konservasi Mangrove Sebagai Pendukung Sumber Hayati Perikanan Pantai. Jurnal Litbang Pertanian, 23(1): 15-21.

Hamilton, L.S. and S.C. Sneaker. 1984. Handbook For Mangrove Area Management. UNEP and East West center. Enviromental and Policy Institute, Honolulu.

Hardjowigeno, S. W. 2001. Kesesuaian Lahan Dan Perencanaan Tataguna Tanah. Tesis. Institut Pertanian Bogor. Bogor

Hogarth, P.J. 2007. The Biology Of Mangroves And Seagrasses. Oxford University Press Inc.New York.

Indriani, D.P., H. Marisa dan Zakaria. 2009. Keanekaragaman Spesies Tumbuhan Pada Kawasan Mangrove Nipah (Nypa Fruticans Wurmb) di Kecamatan Pulau Rimau Kabupaten. Banyuasin Sumatera Selatan. Jurnal Penelitian Sains 12 (3): 1-4 
Indriyanto. 2006. Ekologi Hutan. Jakarta: Penerbit PT Bumi Aksara

Juwita, E., K. Soewardi dan Yonvitner. 2015. Kondisi Habitat Dan Ekosistem Mangrove Kecamatan Simpang Pesak, Belitung Timur Untuk Pengembangan Tambak Udang. Jurnal Manusia dan Lingkungan, 22 (1) : 59-65

Kathiresan, K. dan B.L. Bingham. 2001. Biology of Mangroves and Mangrove Ecosystems. Advance Marine Biology, 40:81-251.

Kjerfve, B. and L.D. Lacerda. 1993. Mangroves of Brazil. In: Lacerda L.D. ed. Conservation and Sustainable Utilization of Mangrove Forests in Latin America and Africa Regions. Part I: Latin America. International Society for Mangrove Ecosystems and the International Tropical Timber Organization.

Kusmana, C., S. Wilarso, I. Hilwan, P. Pamoengkas, C. Wibowo, T. Tiryana, A. Triswanto, Yunasfi dan Hamzah. 2003. Teknik Rehabilitasi Mangrove. Fakultas Kehutanan IPB. Bogor. 177 Hal.

Kusmana C. 2005. Rencana Rehabilitasi Hutan Mangrove dan Hutan Pantai Pasca Tsunami di NAD dan Nias. Makalah dalam Lokakarya Hutan mangrove Pasca sunami, Medan, April 2005.

Kustanti, A. 2011. Manajemen Hutan Mangrove.IPB Press. Bogor. 348 hal.

Macnae, C. 1968. A General Account of The Fauna and Flora of Mangrove Swamps and Forest in the Indo West Pacific Region. Advance. Journal Biology, 6: 73270 .

Mukhlisi, I.G.N. dan B.H. Hartuti P. 2013. Keanekaragaman Jenis dan Struktur Vegetasi Mangrove di Desa Sidodadi Kecamatan Padang Cermin Kabupaten Pesawaran, Provinsi Lampung. Prosiding Seminar Nasional Pengelolaan Sumberdaya Alam dan Lingkungan.

Noor, Y. R., M. Khazali dan I.N.N. Suryadiputra. 2012. Panduan Pengenalan Mangrove Di Indonesia. Cetakan III. Bogor: Wetlands International Indonesia Programme.

Nurdiansah, D. dan I.W.K. Dharmawan. 2018. Komunitas Mangrove di Wilayah Pesisir Pulau
Tidore dan Sekitarnya. Oseanologi dan Limnologi di Indonesia, 3(1): 1-9

Nybakken,W.J. 1988. Biologi Laut: Suatu Pendekatan Ekologis. PT. Gramedia, Jakarta.

Nybakken, J. W. 1993. Marine Biology An Ecological Approach. 3rd Edition. Harper Collins College Publishers, New York.

Parmadi, E.H., I. Dewiyanti dan S. Karina.2016. Indeks Nilai Penting Vegetasi Mangrove Di Kawasan Kuala Idi, Kabupaten Aceh Timur. Jurnal Ilmiah Mahasiswa Kelautan dan Perikanan Unsyiah 1 (1) : 82-95

Prasetyo, A., N. Santoso, dan L.B. Prasetyo. 2017. Kerusakan Ekosistem Mangrove Di Kecamatan Ujung Pangkah Kabupaten Gresik Provinsi Jawa Timur. Jurnal Silvikultur Tropika, 8 (2) : 130133

Saru, A. 2009. Konstibusi Parameter Oseanografi Fisika Terhadap Distribusi Mangrove di Muara Sungai Pangkajene. Jurnal Sains dan Teknologi, 9 (3) : 210- 217

Schaduw, J.N.W. 2018. Distribusi dan Karakteristik Kualitas Perairan Ekosistem Mangrove Pulau Kecil Taman Nasional Bunaken. Majalah Geografie Indonesia 32 (1) ; 40-49

Setiawan, H. 2013. Status Ekologi Hutan Mangrove Pada Berbagai Tingkat Ketebalan. Jurnal Penelitian Kehutanan Wallacea, 2 (2) : 104 120

Supriharyono. 2002. Pelestarian dan Pengelolaan Sumber Daya Alam Di Wilayah Pesisir Tropis. PT. Gramedia Pustaka Utama, Jakarta.

Tahir, I., R.E. Paembonan, Z.A. Harahap, N. Akbar dan E.S. Wibowo. 2017. Sebaran Kondisi Ekosistem Hutan Mangrove Di Kawasan Teluk Jailolo Kabupaten Halmahera Barat Provinsi Maluku Utara. Jurnal Enggano, (2) $2: 15-27$

Thampanya, U., J.E. Vermaat., S. Sinsakul and N. Panapitukkul. 2006. Coastal Erosion and Mangrove Progradation of Southern Thailand. Estuarine, Coastal and Shelf Science 68 (2006): 75-85 